\title{
Cross-species replication of a resistin mRNA QTL, but not QTLs for circulating levels of resistin, in human and baboon
}

\author{
ME Tejero, VS Voruganti, JM Proffitt, JE Curran, HHH Göring, MP Johnson, TD Dyer, JB Jowett, \\ GR Collier, EK Moses, JW MacCluer, MC Mahaney, J Blangero, AG Comuzzie and SA Cole \\ Department of Genetics, Southwest Foundation for Biomedical Research, San Antonio, TX, USA
}

\begin{abstract}
Resistin has been associated with inflammation and risk for cardiovascular disease. We previously reported evidence of a QTL on chromosome 19p13 affecting the abundance of resistin (RETN) mRNA in the omental adipose tissue of baboons (LOD score 3.8). In this study, whole genome transcription levels were assessed in human lymphocyte samples from 1240 adults participating in the San Antonio Family Heart Study, using the Sentrix Human-6 Expression Beadchip. Lymphocytes were surveyed, as it has been proposed that their expression levels may reflect those in harder to ascertain tissues, such as adipose tissue, that are thought to be more directly relevant to disease processes. A genome-wide scan was conducted to detect loci affecting RETN mRNA levels. We obtained significant evidence for a QTL influencing the RETN expression (LOD score 10.7) on chromosome 19p. This region is orthologous/homologous to
\end{abstract}

the region previously localized on baboon chromosome 19. The strongest positional candidate gene in this region is the structural gene for resistin, itself. We also found evidence for a QTL influencing resistin protein levels (LOD score 5.3) on chromosome $14 \mathrm{q}$. This differs from our previously reported QTL on chromosome 18 in baboons. The different QTLs for circulating protein suggests that post-translational processing and turnover may be influenced by different or multiple genes in baboons and humans. The parallel findings of a ciseQTL for RETN mRNA in baboon omental tissue and human lymphocytes lends support to the strategy of using lymphocyte gene expression levels as a surrogate for gene expression levels in other tissues.

Heredity (2008) 101, 60-66; doi:10.1038/hdy.2008.28; published online 30 April 2008

Keywords: inflammation; gene expression; lymphocytes; omental adipose tissue; real time RT-PCR; genome-wide linkage scan

\section{Introduction}

Resistin is a $12.5 \mathrm{kDa}$ peptide produced by numerous tissues in humans, including inflammatory cells (Holcomb et al., 2000; Stumvoll and Haring, 2002). The resistin gene is located on chromosome 19p13 (Steppan et al., 2001). The resistin peptide has been demonstrated to have a role in the regulation of glucose tolerance in mice (Steppan et al., 2001; Banerjee et al., 2004). Initially, resistin was studied as a possible link between adiposity and insulin resistance in humans. However, the association between resistin circulating levels and obesity and type 2 diabetes-related phenotypes is unclear (McTernan et al., 2002; Azuma et al., 2003; Silha et al., 2003; Yannakoulia et al., 2003). Recent reports have found a more consistent association between resistin and inflammatory markers (Lehrke et al., 2004; Bo et al., 2005).

The baboon has been used as a model for the study of obesity and insulin resistance due to its genetic and

Correspondence: Dr ME Tejero, Department of Genetics, Southwest Foundation for Biomedical Research, 7620 NW Loop 410, San Antonio, TX, USA

E-mail: ltejero@sfbrgenetics.org

Received 8 September 2007; revised 11 March 2008; accepted 18 March 2008; published online 30 April 2008 physiologic similarity to humans (Rogers et al., 2000; Banks et al., 2003; Chavez et al., 2008). In both humans and baboons the metabolic response to an increase in body weight is characterized by augmentation of body fat percentage, circulating levels of insulin, insulin resistance, glucose, lipids and lower levels of adiponectin (Banks et al., 2003; Comuzzie et al., 2003; Tejero et al., 2004; Chavez et al., 2008). The baboon resistin (RETN) cDNA sequence is very similar to the reported human sequence (96\% identical) (Tejero et al., 2005). Circulating levels of this protein are similar between the two species. As observed in some human studies, resistin is expressed in baboon adipose tissue and mononuclear cells, and is not associated with body weight (Tejero et al., 2004, 2005).

Circulating levels of human resistin protein and RETN mRNA expression in baboon omental adipose tissue are both heritable, (41 and 24\%, respectively) (Tejero et al., 2005; Menzhagi et al., 2006). Previously, our group identified a significant logarithm of odds (LOD) score of 3.8 on chromosome 19p13 for RETN mRNA levels in omental adipose tissue of baboons (Papio hamadryas), indicating that the gene or genes influencing this trait are located in this chromosomal region (Tejero et al., 2005).

About $80 \%$ of the genes in the human genome are expressed in blood cells. The application of microarray technology to study the transcriptome in circulating cells 
has allowed the exploration of gene expression in lymphocytes as a possible surrogate for other tissues (Burczynski and Dorner, 2006; Liew et al., 2006). In the present study, we conducted a genome-wide scan analysis using RETN mRNA levels in lymphocytes in Mexican Americans from the San Antonio Family Heart Study (SAFHS) (MacCluer et al., 1999; Göring et al., 2007) and compared these results to those we had previously obtained from the baboon using adipose tissue.

\section{Materials and methods}

\section{Study population}

Human study: The SAFHS cohort included 1240 individuals from 42 extended families (including first-, second- and third-degree relatives) of randomly ascertained probands in San Antonio, TX, USA. The study population has been described in detail elsewhere (MacCluer et al., 1999). Lymphocytes were collected from a fasting blood sample for the expression assay. During a second assessment of this population (approximately 10 years later) blood was drawn under fasting conditions and plasma was separated and stored at $-80^{\circ} \mathrm{C}$ for analysis of circulating levels of resistin protein.

Baboon study: The linkage analysis was conducted in 404 adult, pedigreed baboons. Biopsies of omental adipose tissue and blood were collected under fasting conditions and frozen for further analyses. Baboon resistin cDNA was cloned and sequenced for use in the development of the expression assay. Resistin mRNA levels in omental adipose tissue were measured by realtime, quantitative RT-PCR (reverse transcription-PCR). Details on the study sample and methods have been described previously (Tejero et al., 2005).

\section{Biochemical analyses}

Resistin protein quantification was conducted in fasting plasma of a sub-sample of 594 participants from the SAFHS and in 450 baboons (Proffitt et al., unpublished). Samples were assayed with the multiplex kit by Linco Research (Lake Charles, MO, USA).

\section{Genotyping}

Microsatellite genotyping was performed in the SAFHS by PCR using fluorescently-labeled primer pairs from the MapPairs Human Screening Set, versions 6 and 8 (Research Genetics, Huntsville, AL, USA) on lymphocyte-derived DNA samples from study participants. The PCR products were pooled into multiplex panels for genotype calling on an automated DNA sequencer (model 377 with Genescan 672 and Genotyper software programs; Applied Biosystems Inc., Foster City, CA, USA). Individuals were genotyped at 432 highly polymorphic microsatellite markers, distributed with average inter-marker spacing of $<10 \mathrm{cM}$ across all 22 autosomes.

Genotyping of the baboon study has been described elsewhere (Tejero et al., 2005).

\section{Isolation of lymphocytes from fresh blood}

Lymphocytes were collected from 1240 SAFHS participants. A $10 \mathrm{ml}$ blood sample was collected in an EDTA tube and used immediately for isolation of lymphocytes with Histopaque (Sigma Chemical Co., St Louis, MO,
USA). The lymphocyte pellet was washed and frozen in $1 \mathrm{ml}$ of RPMI-C containing $30 \%$ fetal bovine serum and $10 \%$ dimethyl sulfoxide and stored at $-80{ }^{\circ} \mathrm{C}$ for further isolation of total RNA.

\section{Total RNA isolation}

Total RNA was isolated from the lymphyocyte samples using a modified procedure of the QIAGEN RNeasy 96 protocol for isolation of total RNA from animal cells using spin technology (QIAGEN Inc.; Valencia, CA, USA). The freeze medium supernatant solution was aspirated and the pelleted buffy coat samples were resuspended in $250 \mu \mathrm{l}$ of QIAGEN's QIAzol RNase inactivating cell lysis reagent solution. Total RNA yield and purity were determined spectrophotometrically using the NanoDrop ND-1000 (Wilmington, DE, USA). Integrity of resuspended total RNA was determined by electrophoretic separation and subsequent laser induced florescence detection using the RNA 6000 Nano Assay Chip Kit on the Bioanalyzer 2100 using the 2100 Expert software (Agilent Technologies, Waldbronn, Germany). Total RNA integrity was scored by an RNA integrity number, which provides a standardized score on a scale of 1-10. A total of $500 \mathrm{ng}$ total RNA was dried down using an Eppendorf Vacufuge Concentrator 5301 (Eppendorf, Hamburg, Germany) and stored at $-20^{\circ} \mathrm{C}$ prior to anti-sense RNA (aRNA) synthesis, amplification and purification.

Anti-sense RNA synthesis, amplification and purification Anti-sense RNA was synthesized, amplified and purified using the Ambion MessageAmp II Amplification Kit (Ambion; Austin, TX, USA) following the Illumina Sentrix Array Matrix 96-well expression protocol (Illumina Inc.; San Diego, CA, USA). First strand cDNA synthesis was reverse transcribed by resuspending $500 \mathrm{ng}$ of total RNA with a T7 Oligo(dT) primer using an Applied Biosystems 9700 thermal cycler (Applied Biosystems). Secondly, addition of a reverse transcription master mix using Array Script was added to each sample and then incubated at $42^{\circ} \mathrm{C}$ for $2 \mathrm{~h}$. Second strand cDNA synthesis was performed using DNA polymerase and RNase $\mathrm{H}$ by adding a second strand cDNA master mix to the existing first strand cDNA master mix.

Synthesized cDNA samples were purified using QIAGEN's QIAquick 96 PCR purification supplementary protocol for spin technology and dried down using an Eppendorf Vacufuge Concentrator 5301.

Biotin-16-UTP (Roche, Mannheim, Germany) labeled aRNA was synthesized using Ambion's proprietary MEGAscript in vitro transcription technology and T7 RNA Polymerase. A volume of $10 \mu \mathrm{l}$ of aRNA synthesis in vitro transcription master mix was added to the dried purified cDNA samples. This proprietary technology results in thousands of aRNA copies being generated for each mRNA molecule in a single sample. Purification of aRNA samples was performed using QIAGEN's RNeasy 96 protocol for RNA cleanup using spin technology. Changes were made to the two elution steps of QIAGEN's aRNA purification protocol. The first eluate was used for a second elusion, resulting in a more concentrated sample. Anti-sense RNA total yield and purity were determined spectrophotometrically and stored prior to sample hybridization. 
Sample hybridization to illumina beadchip

Hybridization of aRNA to Illumina Sentrix Human Whole Genome (WG-6) BeadChips and subsequent washing, blocking and detecting were performed using Illumina's BeadChip $6 \times 2$ protocol. Purified aRNA $(1.5 \mu \mathrm{g})$ was resuspended in RNase free water and then added to a hybridization mix of pre-warmed Hyb E1 buffer (Illumina) and formamide. aRNA samples (with hybridization mix) were denatured by heating prior to dispensing them onto Illumina's Sentrix Human WG-6 $(6 \times 2)$ BeadChip, which were housed within specifically designed hybridization cartridges. Hybridization cartridges, with BeadChips were placed on a rotary wheel for $16-20 \mathrm{~h}$ at $55^{\circ} \mathrm{C}$ to allow hybridization of aRNA to the oligo substrate. The Illumina Sentrix Human WG-6 BeadChips were washed (E1BC Solution Buffer), blocked (E1 Buffer), signal detected, washed again and then dried prior to scanning. Sample signal detection was developed with the addition of streptavidin-Cy3 (Roche).

Table 1 Descriptive data of the analyzed human sample

\begin{tabular}{|c|c|c|}
\hline & $\begin{array}{c}\text { Male } \\
\mathrm{n}=506\end{array}$ & $\begin{array}{l}\text { Female } \\
\mathrm{n}=734\end{array}$ \\
\hline Age (years) & $38.8(17.7)$ & $39.6(14.5)$ \\
\hline BMI $\left(\mathrm{kg} \mathrm{m}^{-2}\right)$ & $28.1(5.6)$ & $29.8(6.8)$ \\
\hline Resistin mRNA (AU) & $142.5(216.6)$ & $125.5(152.8$ \\
\hline Circulating resistin $\left(\mathrm{ng} \mathrm{ml}^{-1}\right)^{\mathrm{a}}$ & $7.8(3.7)$ & $8.9(3.8)$ \\
\hline
\end{tabular}

Abbreviation: BMI, body mass index.

${ }^{\mathrm{a} C}$ Circulating resistin was measured at a different sample collection. Mean (s.d.).

\section{Sample scanning and detection}

Samples were scanned on the Illumina BeadArray 500GX Reader using Illumina BeadScan image data acquisition software (v 2.3.0.13). The resistin mRNA probe was GI_13435379-S. Illumina BeadStudio software (v 1.5.0.34) was used for preliminary data analysis, with a standard background normalization, to generate an output file for statistcial analysis. To assess quality metrics of each days run, several quality control procedures were implemented. A control RNA sample was analyzed with each daily run. The Illumina BeadStudio software was used to view control summary reports, scatter plots of the control RNA day-to-day and scatter plots of daily run samples. The scatter plots calculated an $r^{2}$ correlation coefficient value. Viewing the scatter plots allowed for daily quality control. This allows for the identification of variation in signal intensity, hybridization signal, background signal and the background to noise ratio level for all samples analyzed on a given day (Göring et al., 2007).

\section{Statistical genetic analysis}

All statistical analyses on related individuals were performed using the variance components-based approach implemented in the software package SOLAR v.4.0 (Almasy and Blangero, 1998). Heritability analysis was performed by decomposing the phenotypic variance into independent genetic and environmental components, assuming an additive model of gene action and expected kinship coefficients based on the observed intra-familial relationships.

The probabilities of identity-by-descent allele sharing among pairs of related individuals were computed by the Markov chain Monte Carlo approach implemented in software package Loki (Heath, 1991) using the genotypes at all linked markers jointly in the computations. The
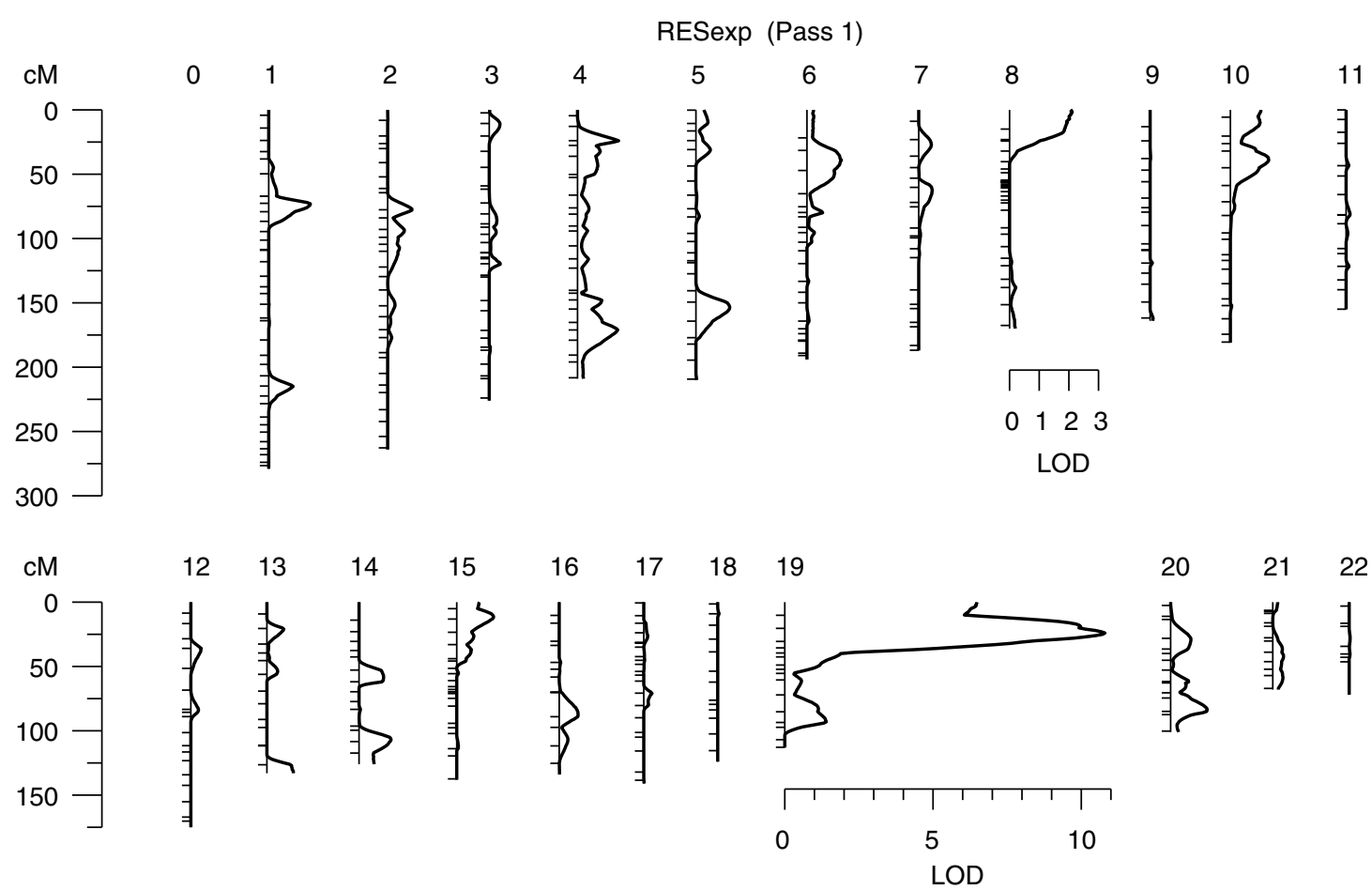

Figure 1 String plot of linkage results for resistin mRNA expression in human lymphocytes. 
a
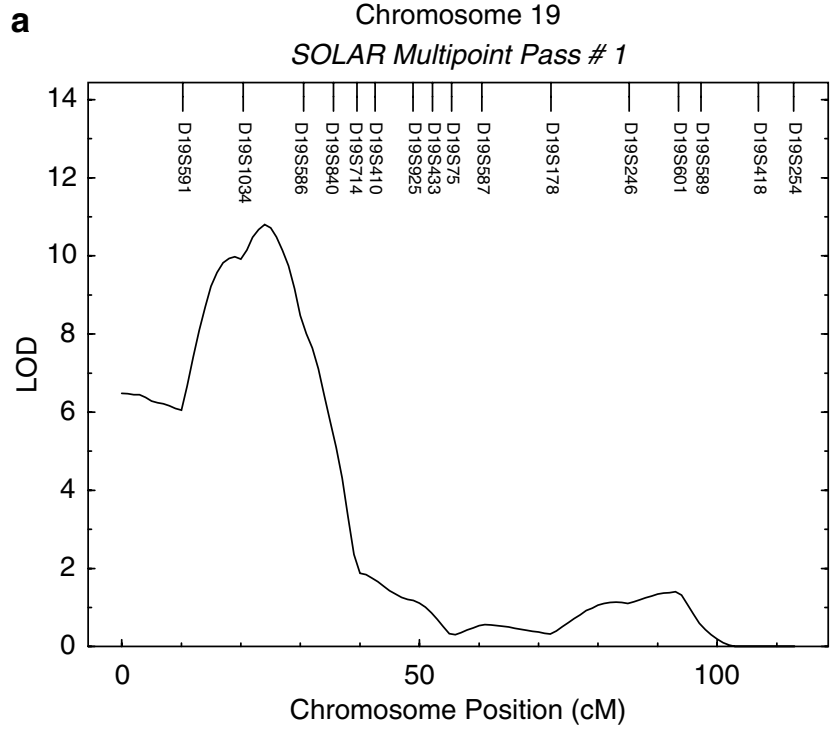

b

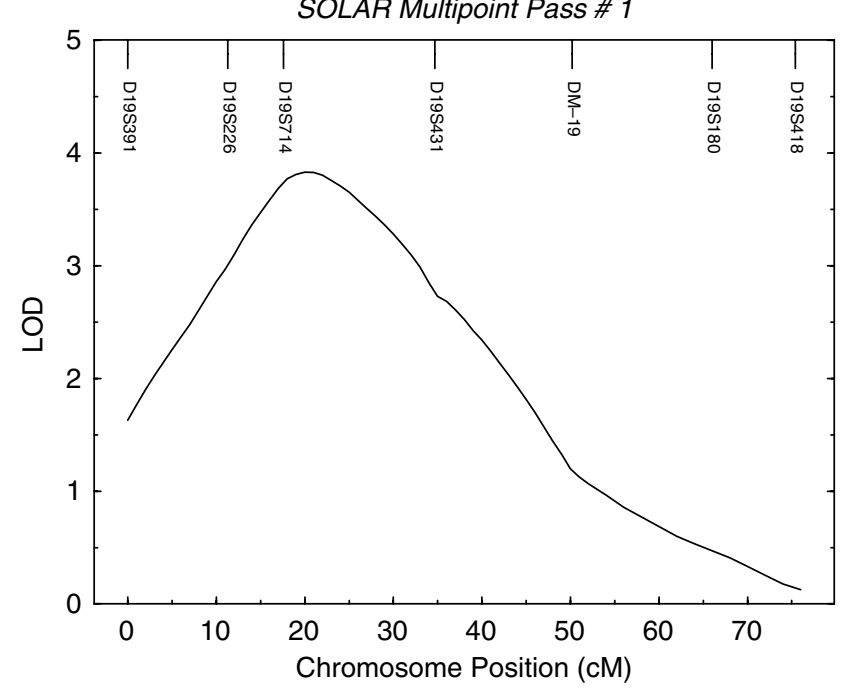

Figure 2 (a) Signal on chromosome 19 of human RETN mRNA in lymphocytes. (b) Signal on chromosome 19 of baboon RETN mRNA levels in omental adipose tissue.

software SOLAR was used to perform a multipoint linkage analysis of RETN expression levels adjusted for sex and age. Maximum likelihood marker allele frequencies (Boehnke, 1991) were used, and the genetic map was based on the one developed by deCODE genetics. We performed linkage analysis to map the genetic factors that influence the expression level of RETN. The baboon genome-wide scan for adipose tissue levels of RETN mRNA and protein levels used the same analytical approach and is described in detail elsewhere (Tejero et al., 2005; Proffitt et al., unpublished).

\section{Results}

Heritability of human RETN mRNA levels in lymphocytes was $41.7 \%$. Descriptive data of the analyzed sample is shown in Table 1. A highly significant LOD score of 10.72 was detected on chromosome 19p13 for RETN
mRNA levels in lymphocytes using sex and age as covariates (Figure 1). The maximum linkage signal for the human RETN expression in human lymphocytes was found between markers D19S1034 and D19S586 (Figure 2a). The strongest positional candidate gene in this region is the resistin gene itself. These results suggest that RETN expression may be cis-regulated, meaning there are variants in or near the resistin gene that influence the abundance of its mRNA. A secondary signal suggestive of linkage was found on chromosome 8 (LOD score =2.1) between markers D8S1099 and D8S1106. Previously, we reported that the heritability of baboon resistin mRNA levels in omental adipose tissue was $0.19(P=0.02)$. Linkage analysis identified a significant LOD score of 3.8 on chromosome 19p between markers D19S226 and D19S431 (Figure 2b) (Tejero et al., 2005).

Human resistin protein was measured in a sub-sample of 549 participants from the original study. This trait was heritable $\left(h^{2}=0.44, P=1.19 \times 10^{-8}\right)$ and significant linkage was found for circulating resistin levels on chromosome $14 \mathrm{q}$ with a LOD score of 5.36 between markers D14S606 and D14S611 (Figures 3 and 4) In a previous study, our group reported a significant heritability $\left(h^{2}=0.71, P=2.9 \times 10^{-10}\right)$ for the levels of baboon resistin protein. A maximum LOD score of 4.0 was found on chromosome 18p for this phenotype. The peak was located $36 \mathrm{cM}$ from pter, between markers D18S475 and D18S172 (Proffitt et al., unpublished).

\section{Discussion}

Human leukocytes are a source for resistin production (Yang et al., 2003). In the present study, the expression levels of human resistin transcripts in lymphocytes seemed to be regulated by the same gene region that influenced its expression in omental adipose tissue in baboons (Tejero et al., 2005). As described by Rogers et al. (2000) the baboon orthologue of human chromosome 19 exhibits the same order among microsatellite markers that is found in the human genome. According to results in both species, the genetic variation influencing the expression of resistin mRNA is located in the 19p13 region, where the RETN gene is located, suggesting that the regulatory element is cis-acting. A previous study identified a single nucleotide polymorphism in the RETN gene associated with resistin mRNA expression levels in human adipose tissue (Smith et al., 2003). Genetic variation in the RETN has been found in association with obesity (Engert et al., 2002) and type 2 diabetes (Ma et al., 2002; Wang et al., 2002). Obesity and diabetes related phenotypes, such as sum of skinfolds, leptin levels and percentage body fat, have been linked to this region on chromosome 19 (Chagnon et al., 2001). The functional variant responsible for the resistin cis-eQTL identified in our study remains to be elucidated.

We identified a suggestive QTL for human lymphocyte RETN mRNA expression on chromosome 8p (Figure 1). QTLs has been reported in this same human chromosomal region for the related phenotypes of body mass index, fat mass and severe obesity (Mitchell et al., 1999; Stone et al., 2002; Perusse et al., 2005). This chromosomal region harbors the $\beta-3$ adrenergic receptor, which has been associated with obesity-related phenotypes including body mass index, fat mass, waist circumference and 


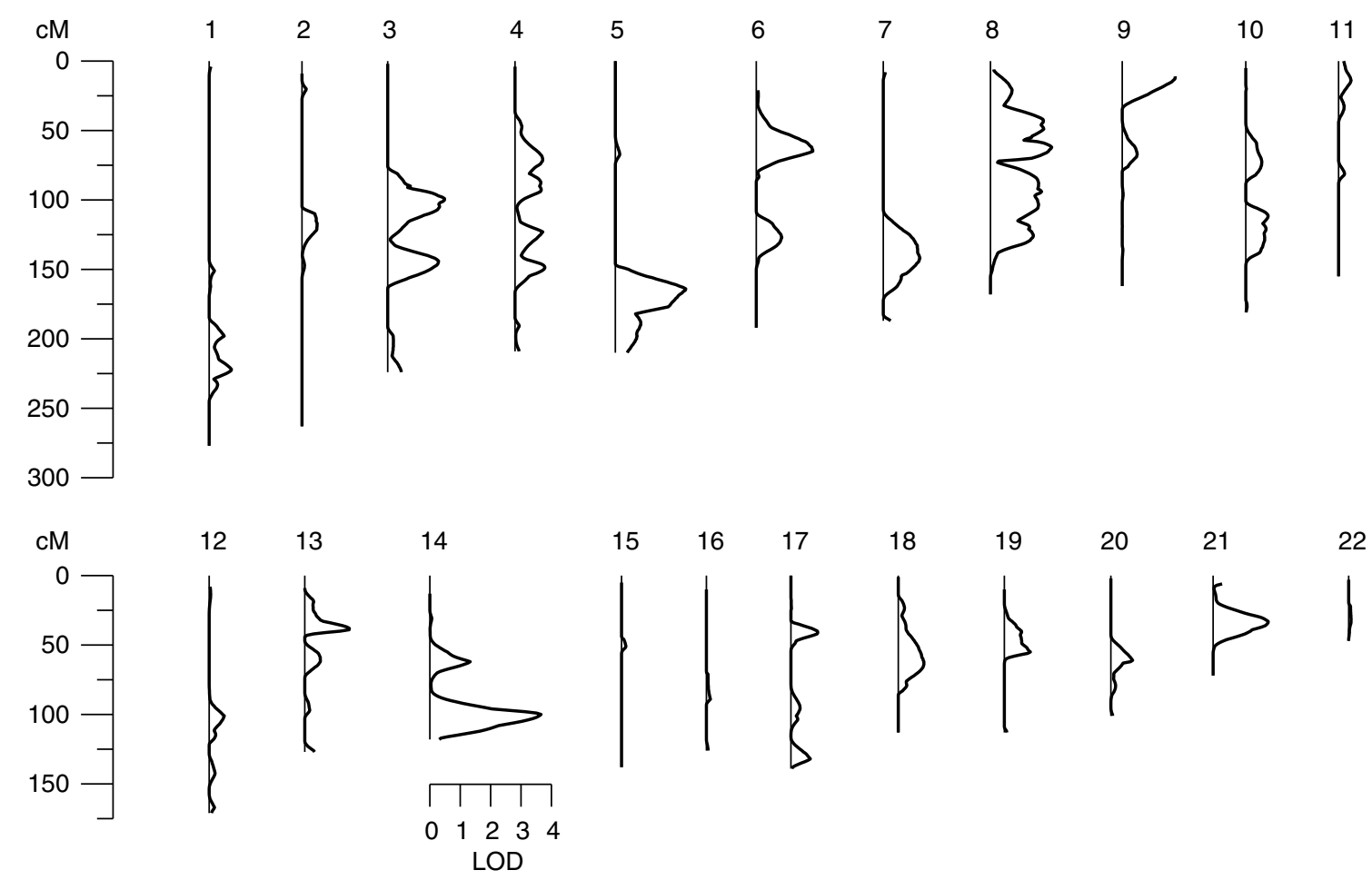

Figure 3 String plot of linkage results for resistin circulating protein in human.

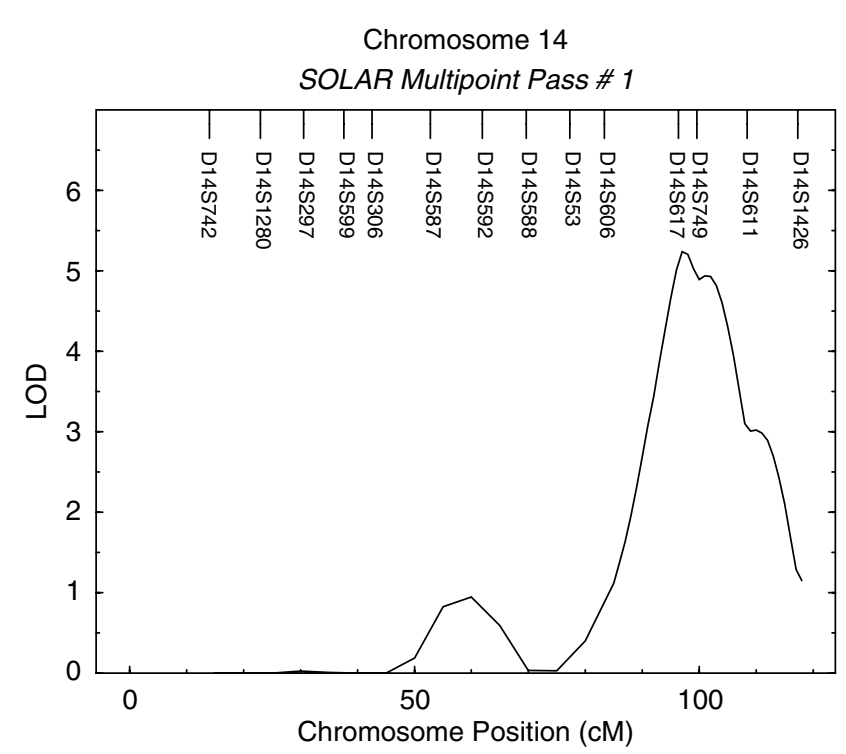

Figure 4 Signal on chromosome 14 for human resistin protein.

body weight in human populations (Mitchell et al., 1999; Perusse et al., 2005). Recently, a gene-cluster polymorphism on 8p23.1 has been associated with low gene copy number of human $\beta$-defensin 2 , which increases predisposition to Crohn's disease, an inflammatory condition (Fellermann et al., 2006). No evidence for linkage of RETN mRNA levels was found on chromosome 8 in the baboon study.
The chromosome 14q region that includes our QTL for circulating resistin levels in the SAFHS has also been linked to leptin (LOD 2.5) (Hsueh et al., 2001), body mass index (LOD 2.2) (Wu et al., 2002) and a phenotype identified as obesity-INS (LOD 2.4). This composite phenotype resulted from factor analysis in a human study on the metabolic syndrome (Kraja et al., 2005). Our QTL region for circulating baboon resistin levels is orthologous to human chromosome 18p. (Proffitt et al., in review).

The genetic and physiologic similarity between baboons and humans has been demonstrated in various studies (Rogers et al., 2000; Banks et al., 2003; Tejero et al., 2004, Chavez et al., 2008). The similarity in the genomes between these two species permits replication of results (Rogers et al., 2000). A previous replication of linkage between the two species has been found using the bone marker osteocalcin, a protein used as a serum marker of osteoblast activity. An earlier human study identified significant linkage to markers D16S753 and D16S771 on chromosome 16q11.1-16q13 (Mitchell et al., 2000).This region was replicated in a genome scan in baboons (Havill et al., 2005).

Peripheral cells express a large proportion of the genes encoded in the human genome including some transcripts considered to be tissue specific, and it is believed to be a possible surrogate tissue for expression of genes in other tissues (Liew et al., 2006). A recent study by Stentz and Kitabchi (2007) has shown that gene expression in lymphocytes and muscle were comparable in type 2 diabetic subjects, and genes involved in the insulin signaling process were reduced in both tissues as compared with matched-non diabetic controls. A study 
by de Mello et al. (2008) indicated that changes in peripheral blood gene expression are responsive to metabolic conditions due to weight loss. Further investigation is required to evaluate the usefulness of gene expression in circulating cells as a potential indicator of gene expression and/or metabolic changes in other tissues. In our study, resistin mRNA levels were linked to homologous regions in humans and baboons, despite the use of different tissues and analytical methods. This observation may be specific for cis-acting elements and supports the future study of gene expression across other tissues and species.

According to our observations, different genes may influence the abundance of RETN mRNA from those that influence circulating protein levels in both humans and baboons. Although our identified eQTL may be cisacting, interestingly, QTLs linked to the circulating protein levels differ in their chromosomal location between humans and baboons, possibly indicating that different or multiple genes are involved in post-translational processing.

Overall, the present study presents novel data on the genetics of resistin expression in two species. Our results support the usefulness of the baboon as a model for the study of genetic factors in complex diseases, and represents one step toward the exploration of the transcriptome of peripheral cells as an indirect measurement for gene expression in other tissues. The anatomical, physiological and genetic similarity between humans and baboons allows for the comparison of the gene expression profiles between circulating cells and other tissues difficult to ascertain such as internal organs or the central nervous system. Further studies are required to establish the applicability of these findings.

\section{Acknowledgements}

This investigation was conducted in a facility constructed with support from Research Facilities Improvement Program Grant Number C06 RR013556 from the National Center for Research Resources, NIH. This work was supported by NIH Grants HL28972 and HL045222. A donation from the Azar and Shepperd families paid for the transcriptional profiling.

\section{References}

Almasy L, Blangero J (1998). Multipoint quantitative-trait linkage analysis in general pedigrees. Am J Human Genet 62: 1198-1211.

Azuma K, Katsukawa F, Oguchi S, Murata M, Yamazaki H, Shimada A et al. (2003). Correlation between serum resistin level and adiposity in obese individuals. Obes Res 11: 997-1001.

Banerjee RR, Rangwala SM, Shapiro JS, Rich AS, Rhoades B, Qi Y et al. (2004). Regulation of fasted blood glucose by resistin. Science 303: 1195-1198.

Banks WA, Altmann J, Sapolsky RM, Phillips-Conroy JE, Morley JE (2003). Serum leptin levels as a marker for a syndrome X-like condition in wild baboons. J Clin Endocrinol Metabol 88: 1234-1240.

Bo S, Gambino R, Pagani A, Guidi S, Gentile L, Cassader M et al. (2005). Relationships between human serum resistin, inflammatory markers and insulin resistance. Int J Obes 29: 1315-1320.

Boehnke M (1991). Allele frequency estimation from data on relatives. Am J Hum Genet 48: 22-25.
Burczynski ME, Dorner AJ (2006). Transcriptional profiling of peripheral blood cells in clinical pharmacogenomic studies. Pharmacogenomics 7: 187-202.

Chagnon Y, Rice T, Perusse L, Borecki IB, Ho-Kim MA, Lacaille M et al. (2001). Genomic scan for genes affecting body composition before and after training in Caucasians from HERITAGE. J Appl Physiol 90: 1777-1787.

Chavez AO, López Alvarenga JC, Tejero ME, Tripplit C, Bastarrachea R (2008). Physiologic and molecular determinants of insulin actions in the baboon. Diabetes 57: 899-908.

Comuzzie AG, Cole SA, Martin L, Dee Carey K, Mahaney MC, Blangero J et al. (2003). The baboon as a nonhuman model for the study of the genetics of obesity. Obes Res 11: 75-80.

De Mello V, Kolehmainen M, Schwab U, Mager U, Laaksonen DE, Pulkkinen L et al. (2008). Effect of weight loss on cytokine messenger RNA expression in peripheral blood mononuclear cells of obese subjects with the metabolic syndrome. Metabolism 57: 192-199.

Engert JC, Vohl MC, Williams SM, Lepage P, Loredo-Osti JC, Faith J et al. (2002). $5^{\prime}$ flanking variants of resistin are associated with obesity. Diabetes 51: 1629-1634.

Fellermann K, Stange DE, Schaeffeler E, Schmalzl H, Wehkamp J, Bevins CL et al. (2006). A chromosome 8 gene-cluster polymorphism with low human beta-defensin 2 gene copy number predisposes to crohn disease of the color. Am J Hum Gene 79: 439-448.

Göring HH, Curran JE, Johnson MP, Dyer TD, Charlesworth J, Cole SA et al. (2007). Discovery of expression QTLs using large-scale transcriptional profiling in human lymphocytes. Nat Genet 39: 1208-1216.

Havill LM, Cox LA, Rogers J, Mahaney MC (2005). Crossspecies replication of a serum osteocalcin quantitative trait locus on human chromosome $16 \mathrm{q}$ in pedigreed baboons. Calcif Tissue Int 77: 1-7.

Heath SC (1991). Markov chain Monte Carlo segregation and linkage analysis for oligogenic models. Am J Hum Genet 61: 748-760.

Holcomb IN, Kabakoff RC, Chan B, Baker TW, Gurney A, Henzel W et al. (2000). FIZZ1, a novel syteine-rich secreted protein associated with pulmonary inflammation, defines a new gene family. EMBO J 19: 4046-4055.

Hsueh WC, Mitchell BD, Schneider JL, St Jean PL, Pollin TI, Ehm MG et al. (2001). Genomewide scan of obesity in the Old Order Amish. J Clin Endocrinol Metab 86: 1199-1205.

Kraja AT, Hunt SC, Pankow JS, Myers RH, Heiss G, Lewis CE et al. (2005). Quantitative trait loci for metabolic syndrome in the hypertension genetic epidemiology network study. Obes Res 13: 1885-1890.

Lehrke M, Reilly MP, Millington SC, Iqbal N, Rader DJ, Lazar MA (2004). An inflammatory cascade leading to hyperresistinemia in humans. PLoS Med 1: 165-168.

Liew CC, Ma J, Tang HC, Zheng R, Dempsey AA (2006). The peripheral blood transcriptome reflects system wide biology: a potential diagnostic tool. J Lab Clin Med 147: 126-132.

Ma X, Warram JH, Trischitta V, Doria A (2002). Genetic variants at the resistin locus and risk of type 2 diabetes in Caucasians. J Clin Endocrinol Metab 87: 4407-4410.

MacCluer JW, Stern MP, Almasy LA, Atwood LA, Blangero J, Comuzzie AG et al. (1999). Genetics of atherosclerosis risk factors in Mexican Americans. Nutr Reviews 57: S59-S65.

McTernan P, Mc Ternan C, Chetty R, Jenner K, Fisher FM, Lauer M et al. (2002). Increased resistin gene and protein expression in human abdominal adipose tissue. J Clin Endocrinol Metab 87: 2407-2410.

Mitchell BD, Cole SA, Bauer RL, Iturria SJ, Rodríguez EA, Blangero J et al. (2000). Genes influencing variation in serum osteocalcin concentrations are linked to markers on chromomes 16q and 20q. J Clin Endocrinol Metabol 85: 1362-1366.

Mitchell BD, Cole SA, Comuzzie AG, Almasy L, Blangero J, Maccluer JW et al. (1999). A quantitative trait locus influen- 
cing BMI maps to the region of the beta-3 adrenergic receptor. Diabetes 48: 1863-1867.

Menzhagi C, Coco A, Saveomo J, Thompson R, De Cosmo S, Doria A et al. (2006). Heritability of serum resistin and its genetic correlation with insulin resistance-related features in nondiabetic Caucasians. I Clin Endocrinol Metab 91: 2792-2795.

Perusse L, Rankinen T, Zuberi A, Chagnon YC, Weisnagel SJ, Argyropoulos G et al. (2005). The human obesity gene map: the 2004 update. Obes Res 13: 381-490.

Proffitt JM, Tejero ME, Freeland-Graves JH, Cole SA, Blangero J et al. A quantitative trait locus influencing plasma resistin levels in healthy baboons resides on chromosome 18. Animal Genet In review.

Rogers J, Mahaney MC, Witte SM, Nair S, Newman D, Wedel S et al. (2000). A genetic linkage map of the baboon (Papio hamadyas) genome based on human microsatellite polymorphisms. Genomics 67: 237-247.

Silha JV, Krsek M, Skrha JV, Sucharda P, Nyomba BLG, Murphy L (2003). Plasma resistin, adiponectin and leptin levels in lean and obese subjects: correlations with insulin resistance. Euro J Endocrinol 149: 331-335.

Smith SR, Bai F, Charbonneau Ch, Janderova L, Argyropoulos G (2003). A promoter genotype and oxidative stress potentially link resistin to human insulin resistance. Diabetes $\mathbf{5 2}$ 1611-1618.

Stentz FB, Kitabchi AE (2007). Transcriptome and proteome expressions involved in insulin resistance in muscle activated T-lymphocytes of patients with type 2 diabetes. Genomics Proteomics Bioinformatics 5: 216-235.

Steppan C, Bailey ST, Bhat S, Brown EJ, Banerjee RR, Wright CM et al. (2001). The hormone resistin links obesity to diabetes. Nature 409: 307-312.
Stone S, Abkevich V, Hunt SC, Gutin A, Russell DL, Neff CD et al. (2002). A major predisposition locus for severe obesity at 4p15-p14. Am J Hum Gent 70: 1459-1468.

Stumvoll M, Haring H (2002). Resistin and adiponectin-of mice and men. Obes Res 10: 1197-1198.

Tejero ME, Cole SA, Cai G, Peebles KW, Freeland-Graves JH, Cole SA et al. (2005). Genome-wide scan of resistin mRNA expression in omental adipose tissue of baboons. Int J Obes 29: 406-412.

Tejero ME, Freeland-Graves JH, Proffitt JM, Peebles KW, Cole SA, Comuzzie AG (2004). Adiponectin, but not resistin expression in monocytes is associated with insulin resistance in baboons. Obes Res 12: 871-877.

Wang H, Chu WS, Hemphill C, Elbein SC (2002). Human resistin gene: molecular scanning and evaluation of association with insulin sensitivity and type 2 diabetes in Caucasians. J Clin Endocrinol Metab 87: 2520-2524.

Wu X, Cooper RS, Borecki I, Hanis C, Bray M, Lewis CE (2002). A combined analysis of genomewide linkage scans for body mass index from the National Heart, Lung, and Blood Institute Family Blood Pressure Program. Am J Hum Genet 70: 1247-1256.

Yang RZ, Huang Q, Xu A, McLenithan JC, Eison JA, Shuldiner AR et al. (2003). Comparative studies of resistin expression and phylogenomics in human and mouse. Biochem Biophys Res Comm 310: 927-935.

Yannakoulia M, Yiannakouris N, Bluher S, Mtalas AL, Klimis D, Mantzoros C (2003). Body fat mass and macronutrient intake in relation to circulatin soluble leptin receptor, free leptin index, adiponectin, and resistin concentrations in healthy humans. J Clin Endocrinol Metabol 88: $1730-1736$ 